Ventions, LLC; DE-FG36-06G016050

FinAl SCIENTIFIC / TECHNICAL REPORT

DOE AWARD NUMBER: DE-FG36-06G016050

RECIPIENT: VENTIONS, LLC

\title{
A LOW-COST, HIGH EFFICIENCY PERIODIC FLOW GAS TURBINE FOR \\ DISTRIBUTED ENERGY GENERATION
}

\author{
Project Director / Principal Investigator: \\ Dr. Adam P. London \\ Ventions, LLC \\ 818 Duncan Street \\ San Francisco, CA 94131 \\ Ph: (415) 730-5362 \\ Email: adam.london@ventions.com
}

Date Report was Prepared:

June 20, 2008 


\section{EXECUTIVE SUMMARY}

Adding to the area being investigated: To-date, the widespread commercialization of microturbines for distributed power generation has largely been limited by their relatively high capital cost $(\$ 1,000 / \mathrm{kW})$, and low thermal efficiencies (28\%). The project therefore served as a feasibility study for development of an innovative micro gas turbine engine capable of realizing higher thermal-to-electric efficiencies in the $39 \%-48 \%$ range, and 40\% lower manufacturing costs compared to state-of-the-art microturbine designs.

Overall, this innovation to realize low-cost microturbines with thermal efficiencies in the 39-48\% range will support EERE's stated goals of strengthening America's energy security, environmental quality and economic vitality by enabling clean high efficiency distributed energy generation to improve the reliability and efficiency of electricity generation and delivery.

Furthermore, microturbines have already been identified by the EERE's Distributed Energy Program as having high economic potential because of their small number of moving parts, compact size, light weight and low emissions - since the proposed improvements in recuperator technology developed as part of the effort are key to improving the economics of current microturbine systems, the effort fits in well with DoE's active research areas.

Technical effectiveness and economic feasibility of the techniques: The project used a combination of analytical, computational and experimental methods to evaluate the technical and economic feasibility of an innovative periodic flow gas turbine. As such, it focused on several key elements including:

- Overall system design, configuration layout, CAD modeling, and performance projection;

- Component and system cost modeling to validate economic savings claims;

- CFD-based design and experimental testing of a set of passively actuated nozzle guide vanes capable of bi-directional flow;

- CFD analysis of a bi-directional combustor to evaluate pressure loss;

- Design, fabrication and experimental testing of a periodic flow combustor test rig; and

- Identification, procurement and experimental validation of a set of low-cost valves capable of switching the flow in the proposed periodic flow engine.

The results of these activities successfully validated performance claims, while reducing risk in some of the critical components of the proposed innovation, namely, passively-activated bi-directional nozzle guide vanes, a low-loss reversible flow combustor, and low-cost, long-life valves capable of 4-way flow switching with minimal actuation delays.

Project benefits to the public: The proposed technology is fundamentally based on a microturbine; hence, it provides many of the same advantages as state-of-the-art microturbines currently available (lowemissions, low-noise, versatility in applications, etc.). The primary difference and advantage however, arises from replacement of an expensive recuperator with a lower-cost, high-effectiveness regenerator to increase cycle thermal efficiency from approximately $28 \%$ to $39 \%$ (and potentially up to $48 \%$ through use of a low-cost and robust ceramic turbine), while simultaneously providing a $40 \%$ reduction in capital cost.

In doing so, the proposed system is expected to allow for significant energy savings, as quantified on the following page for two different configurations of a $100 \mathrm{~kW}$ baseline design assumed to operate at a $50 \%$ duty cycle (the first configuration represents a near-term design with a conservative efficiency level of $39 \%$ for a non-ceramic version; the second configuration represents a longer-term ceramics-based design with $48 \%$ efficiency). The values are additionally compared with a current state-of-the-art (SOA) turbine operating at $28 \%$ efficiency. 
Ventions, LLC; DE-FG36-06G016050

\begin{tabular}{|l|cccccc|}
\hline & $\begin{array}{c}\text { Electrical } \\
\text { Output }\end{array}$ & $\begin{array}{c}\text { Cycle } \\
\text { Efficiency }\end{array}$ & $\begin{array}{c}\text { Thermal } \\
\text { Input }\end{array}$ & $\begin{array}{c}\text { Yearly } \\
\text { Usage }\end{array}$ & $\begin{array}{c}\text { Yearly } \\
\text { Conversion }\end{array}$ & $\begin{array}{c}\text { Thermal } \\
\text { Input }\end{array}$ \\
\cline { 2 - 7 } & $k W$ & - & $k W$ & $h r / y r$ & $M B T U / k W h$ & $M B T U / y r$ \\
\hline SOA Microturbine & 100 & $28 \%$ & 357 & 4,380 & 0.0034 & 5,339 \\
\hline $\begin{array}{l}\text { PFGT - Near Term } \\
\text { Savings }\end{array}$ & 100 & $39 \%$ & 256 & 4,380 & 0.0034 & 3,833 \\
\hline $\begin{array}{l}\text { PFGT - Potential } \\
\text { Savings }\end{array}$ & 100 & $48 \%$ & 208 & 4,380 & 0.0034 & 3,114 \\
\hline
\end{tabular}

Furthermore, assuming that all of the annual demand of approximately 1,000 microturbines is fulfilled using the proposed periodic-flow gas turbine in the $100 \mathrm{~kW}$ size-class, the projected total US energy savings are quantified below:

\begin{tabular}{|c|c|c|c|c|c|c|c|c|}
\hline & $\begin{array}{c}\text { Electrical } \\
\text { Output }\end{array}$ & $\begin{array}{c}\text { Market } \\
\text { Size }\end{array}$ & $\begin{array}{c}\text { Electrical } \\
\text { Output }\end{array}$ & $\begin{array}{c}\text { Cycle } \\
\text { Efficiency }\end{array}$ & $\begin{array}{c}\text { Thermal } \\
\text { Input }\end{array}$ & $\begin{array}{l}\text { Yearly } \\
\text { Usage }\end{array}$ & Conversion & $\begin{array}{l}\text { Yearly } \\
\text { Thermal } \\
\text { Input }\end{array}$ \\
\hline & kW/Unit & Units & $k W$ & - & $k W$ & $h r / y r$ & MBTU/kWh & $M B T U / y r$ \\
\hline SOA Microturbine & 100 & 1000 & 100,000 & $28 \%$ & 357143 & 4,380 & 0.0034 & $5,338,907$ \\
\hline $\begin{array}{l}\text { PFGT - Near Term } \\
\text { Savings }\end{array}$ & 100 & 1000 & 100,000 & $39 \%$ & 256410 & 4,380 & 0.0034 & $\begin{array}{l}3,833,062 \\
\mathbf{1 , 5 0 5 , 8 4 6}\end{array}$ \\
\hline $\begin{array}{l}\text { PFGT - Potential } \\
\text { Savings } \\
\text { After } 10 \mathrm{yr}\end{array}$ & 100 & 1000 & 100,000 & $48 \%$ & 208333 & 4,380 & 0.0034 & $\begin{array}{r}3,114,363 \\
\mathbf{2 , 2 2 4 , 5 4 5} \\
\mathbf{2 2 , 2 4 5 , 4 4 6}\end{array}$ \\
\hline
\end{tabular}

Overall, while all microturbines offer the advantage of reduced emissions relative to other non-renewable means of distributed power generation; the proposed concept is estimated to offer an additional $15-40 \%$ reduction in $\mathrm{CO}_{2}$ and other pollutant emissions relative to SOA microturbine technologies.

As tabulated below, the proposed system realizes a greater reduction in $\mathrm{CO}_{2}$ emissions based on a much higher overall efficiency than state of the art microturbines (a ceramic-based periodic flow turbine operating at $48 \%$ efficiency (PFGT-Potential) is expected to reduce $\mathrm{CO}_{2}$ emissions by $42 \%$ relative to stand-alone microturbines, and by $15 \%$ relative to SOA microturbines that incorporate CHP).

\begin{tabular}{|c|c|c|c|c|c|}
\hline \multirow[b]{2}{*}{ Plant type } & \multirow{2}{*}{$\begin{array}{c}\text { Fuel Carbon } \\
\text { Content } \\
k g-C / G J\end{array}$} & \multicolumn{2}{|c|}{ Baseline system } & \multicolumn{2}{|c|}{ CHP - $50 \%$ recovery } \\
\hline & & $\begin{array}{c}\text { Overall } \\
\text { Efficiency }\end{array}$ & $\begin{array}{c}\text { CO2 Emissions } \\
k g-C / M W h\end{array}$ & $\begin{array}{c}\text { Overall } \\
\text { Efficiency }\end{array}$ & $\begin{array}{c}\text { CO2 Emissions } \\
k g-C / M W h\end{array}$ \\
\hline Coal-fired (grid) & 24.5 & $34 \%$ & 256 & $34 \%$ & 256 \\
\hline CCGT (grid) & 13.8 & $54 \%$ & 92 & $54 \%$ & 92 \\
\hline SOA Microturbine & 13.8 & $28 \%$ & 177 & $64 \%$ & 78 \\
\hline PFGT - Near Term & 13.8 & $39 \%$ & 127 & $70 \%$ & 71 \\
\hline $\begin{array}{l}\text { PFGT - Potential } \\
\text { vs SOA MT } \\
\text { vs CCGT }\end{array}$ & 13.8 & $48 \%$ & $\begin{array}{c}104 \\
-42 \% \\
+12 \%\end{array}$ & $74 \%$ & $\begin{array}{c}67 \\
-14 \% \\
-27 \%\end{array}$ \\
\hline
\end{tabular}

Note: Coal-fired and CCGT efficiency assumptions include $7 \%$ transmission/distribution losses

Correspondingly, estimates for $\mathrm{NO}_{\mathrm{x}}$ and $\mathrm{CO}$ emissions are based on the fact that since reaction rates scale as square root of pressure, emissions per unit primary zone airflow are expected to be $30-35 \%$ lower than a comparable SOA combustor operating at $4.5 \mathrm{~atm}$ (versus $2 \mathrm{~atm}$ in the proposed system) ${ }^{1}$.

\begin{tabular}{|l|c|c|c|c|c|c|}
\hline \multirow{2}{*}{} & \multicolumn{2}{|c|}{ NOx } & \multicolumn{2}{c|}{ CO } & \multicolumn{2}{c|}{ THC } \\
\cline { 2 - 7 } & $p p m$ & $l \mathrm{~b} / \mathrm{MW}-\mathrm{hr}$ & $p p m$ & $\mathrm{Ib} / \mathrm{MW}-\mathrm{hr}$ & $p p m$ & $\mathrm{Ib} / \mathrm{MW}-\mathrm{hr}$ \\
\hline SOA Capstone Microturbine (30kW) & 9 & 0.49 & 40 & 1.33 & 9 & $\mathbf{0 . 1 7}$ \\
Other Microturbine (45-75kW) & $9-25$ & $0.5-1.5$ & $25-240$ & $1.3-9$ & $9-25$ & $.04-0.5$ \\
\hline PFGT - Near Term & 4 & 0.32 & 16 & 0.86 & 4 & 0.11 \\
PFGT - Potential & 8 & 0.42 & 35 & 1.13 & 8 & 0.14 \\
\hline Industrial Turbines (0.8-11MW) & $6-140$ & $0.9-2.0$ & $1-462$ & $0.7-2.0$ & $6-559$ & $0.1-0.3$ \\
IC Engines (170kW-1500kW) & $30-3214$ & $1.5-30$ & $325-833$ & $6-30$ & 2747 & $0.6-7$ \\
\hline
\end{tabular}

${ }^{1} \mathrm{CO}$ emissions increase at lower temperatures; $\mathrm{NO}_{\mathrm{x}}$ emission increase with temperature; hence, in order to balance both of these, the PFGT combustor is designed to operate with a primary zone (where combustion and most pollutant production actually occurs) in the same optimum temperature band (1670K - 1900K) as SOA combustors. 


\section{Description of the Periodic Flow Gas Turbine Concept}

The periodic-flow microturbine design being developed under the stated effort is illustrated in the figure below:

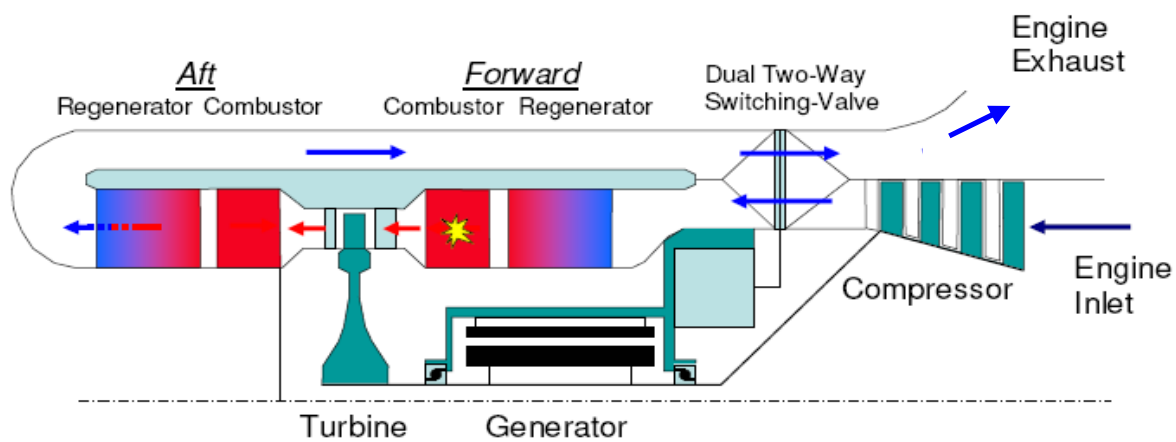

As shown in this "Cycle-1" schematic, flow enters the engine compressor from right-to-left and passes through a two-way, "cold" switching-valve that directs it into the lower hot-section of the micro-turbine. The flow then passes through a regenerator ceramic matrix where it gains the energy that is stored in the matrix, thereby preheating it prior to additional heat addition in the combustor. Continuing to flow from right-to-left, it is then expanded through the turbine, wherein power is extracted to drive the compressor and run an electrical generator. Finally, it flows through a second regenerator matrix at the aft-end of the engine to transfer its residual energy into the ceramic matrix, and then eventually flows-out through the radially-outboard exhaust of the engine. (Note that Cycle-1 entails storage of energy in the aftregenerator, and release in the forward-regenerator.)

Cycle-2, as shown below, involves switching the cold-valve such that compressed flow is now directed around the engine and first enters the aft-regenerator from left-to-right, picking-up the energy stored during the previous cycle. It then gains additional heat in the aft-combustor, has work extracted by the same turbine, passes through the "passive" front-combustor into the forward-regenerator to deposit energy into its ceramic matrix, and finally exhaust through the front-end.

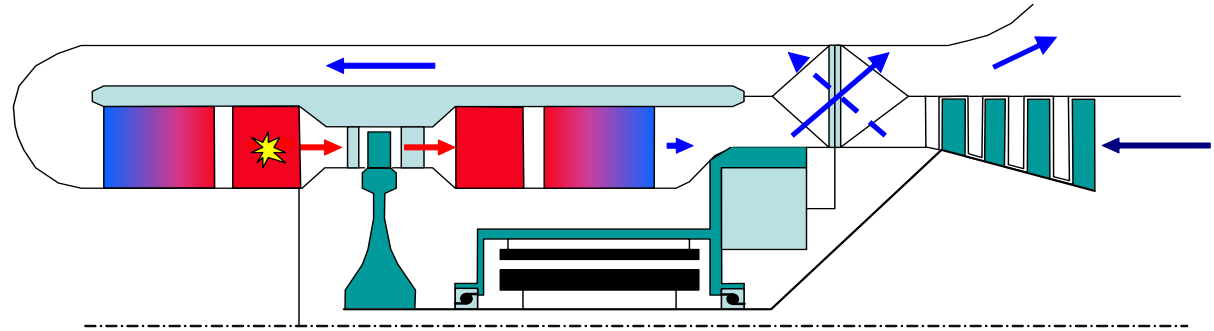

At this point, energy is stored in the forward-regenerator and released in the aft-regenerator; the engine is now ready to switch back to Cycle-1, such that periodic repetition between the two operating modes provides an effective means of capturing and reusing turbine waste heat without the need for complex valves or seals to operate at high temperatures.

Additional key features in the proposed engine design include use of:

- An impulse turbine with guide vanes that can be aerodynamically reconfigured to serve as either inlet or exit vanes, depending on flow direction (this is especially suitable for impulse turbines that have axial symmetry, appearing aerodynamically similar in forward and reverse flow-conditions);

- Identical combustors on either side of the turbine to alternate heat addition at both locations; and

- An annular two-way switching valve in the cold-section of the engine to alternate compressor discharge flow between the forward and reverse-flow directions, while simultaneously allowing the exhaust gas to exit through fixed ports. 


\section{COMPARISON OF ACTUAL ACCOMPlishments With PROJECT GOALS AND OBJECTIVES}

The stated effort had several key goals and objectives, as laid out in the original proposal in the form of key technical / economic feasibility questions:

1. Does a detailed design, configuration lay-out and cost-model support expected projections for a $39 \%$ efficient microturbine priced at $\$ 600 / \mathrm{kW}$ ?

2. Does a $1^{\text {st }}$ order analytical design and performance assessment support the assumption of $>95 \%$ regenerator effectiveness with low-enough pressure loss to meet overall performance goals?

3. Can a two-way switching valve be used to modulate flow through an annular configuration within the required time-constants of the proposed system?

4. Can aerodynamic forces be used to passively actuate the vanes in a reversible-flow turbine?

5. Can a suitable combustion system be designed and operated to periodically re-light while attaining requisite turbine inlet temperatures?

6. Is there an optimal set of materials for each component that enables realization of a low-cost engine?

The work to-date reported herein successfully answered all of the above, and didn't reveal any significant "show-stoppers" or hurdles for future development of the proposed periodic flow gas turbine. Specifically:

- Detailed design, configuration layout and cost modeling supported initial estimates and claims;

- A low-cost, high-speed, long-life switching valve was indeed identified, procured and tested to validate feasibility for use in the proposed system;

- Aerodynamic forces were successfully shown to be capable of passively actuating nozzle guide vanes in a reversible flow environment;

- CFD analysis of a suitable combustion system showed satisfactory pressure loss in reversible flow configurations; and

- A set of materials were identified for each component in the engine, and formed the basis of a granular cost model.

A detailed table showing planned activities, and their actual date of completion is shown alongside.

\begin{tabular}{|c|l|c|c|}
\hline \multirow{2}{*}{ Task \# } & \multicolumn{1}{|c|}{ Task Description } & \multicolumn{2}{c|}{ Task Completion Dates } \\
\cline { 3 - 4 } & & Original Planned & Actual \\
\hline 1 & Design / size engine components & $9 / 20 / 2006$ & $9 / 30 / 2006$ \\
\hline 2 & Plan vane test experiment & $9 / 25 / 2006$ & $9 / 25 / 2006$ \\
\hline 3 & Plan combustor experiment & $9 / 10 / 2006$ & $9 / 25 / 2006$ \\
\hline 4 & Update component performance models & $10 / 10 / 2006$ & $10 / 31 / 2007$ \\
\hline 5 & Update cycle deck & $11 / 10 / 2006$ & $11 / 30 / 2007$ \\
\hline 6 & Undertake materials / structural analysis & $10 / 15 / 2006$ & $5 / 31 / 2007$ \\
\hline 7 & Design / layout baseline engine & $11 / 10 / 2006$ & $2 / 15 / 2007$ \\
\hline 8 & Design combustor test rig & $11 / 10 / 2006$ & $8 / 31 / 2007$ \\
\hline 9 & Design vane test rig & $1 / 15 / 2007$ & $2 / 15 / 2007$ \\
\hline 10 & Develop component cost models & $11 / 25 / 2006$ & \multirow{2}{*}{$5 / 31 / 2007$} \\
\hline 11 & Develop integrated cost model & $12 / 15 / 2006$ & \\
\hline 12 & Review regenerator literature & $11 / 10 / 2006$ & \multirow{2}{*}{$3 / 31 / 2007$} \\
\hline 13 & Conduct fluid dynamic design & $12 / 10 / 2006$ & \\
\hline 14 & Conduct regenerator heat transfer / structure design & $12 / 25 / 2006$ & \\
\hline 15 & Define valve requirements & $11 / 15 / 2006$ & $11 / 15 / 2006$ \\
\hline 16 & Identify potential valves & $12 / 10 / 2006$ & $6 / 30 / 2007$ \\
\hline 17 & Procure / test valves & $1 / 20 / 2007$ & $8 / 31 / 2007$ \\
\hline 18 & Fabricate / setup combustor rig & $1 / 25 / 2007$ & $10 / 31 / 2007$ \\
\hline 19 & Conduct combustion experiments & $3 / 15 / 2007$ & $12 / 31 / 2007$ \\
\hline 20 & Fabricate / setup vane test rig & $3 / 15 / 2007$ & $3 / 15 / 2007$ \\
\hline 21 & Conduct vane test rig experiments & $4 / 15 / 2007$ & $3 / 15 / 2007$ \\
\hline 22 & Final wrap-up; updating models & $4 / 30 / 2007$ & $2 / 29 / 2008$ \\
\hline 23 & CFD evaluation of turbine NGV actuation & New Task Added & $3 / 15 / 2007$ \\
\hline 24 & CFD evaluation of losses in combustor & New Task Added & $6 / 30 / 2007$ \\
\hline & & \multicolumn{2}{|c}{} \\
\hline
\end{tabular}




\section{SuMmary OF Project ACTIVITIES}

The stated effort focused on 6 key activities described in detail below:

1. Overall system design, configuration layout and CAD modeling: The project was initiated by converting the initially propose concept for the periodic flow gas turbine into a detailed system CAD model, complete with material choices for each of the components.

Pictures of the final concepts are reproduced below:

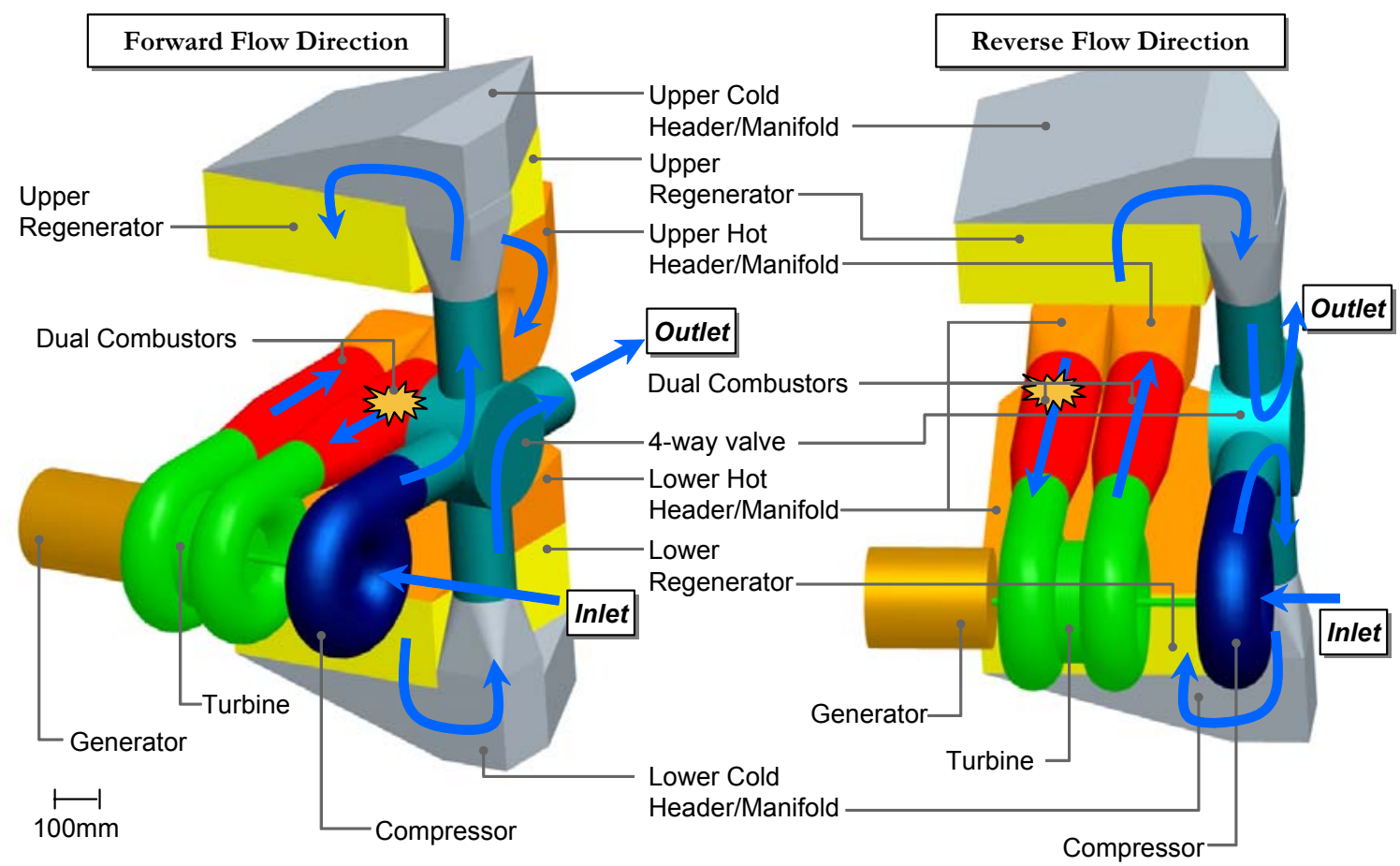

The CAD modeling effort was subsequently expanded to include details of the turbomachinery components (bottom left image), as well as complete the layout in a packaged configuration (bottom right image).
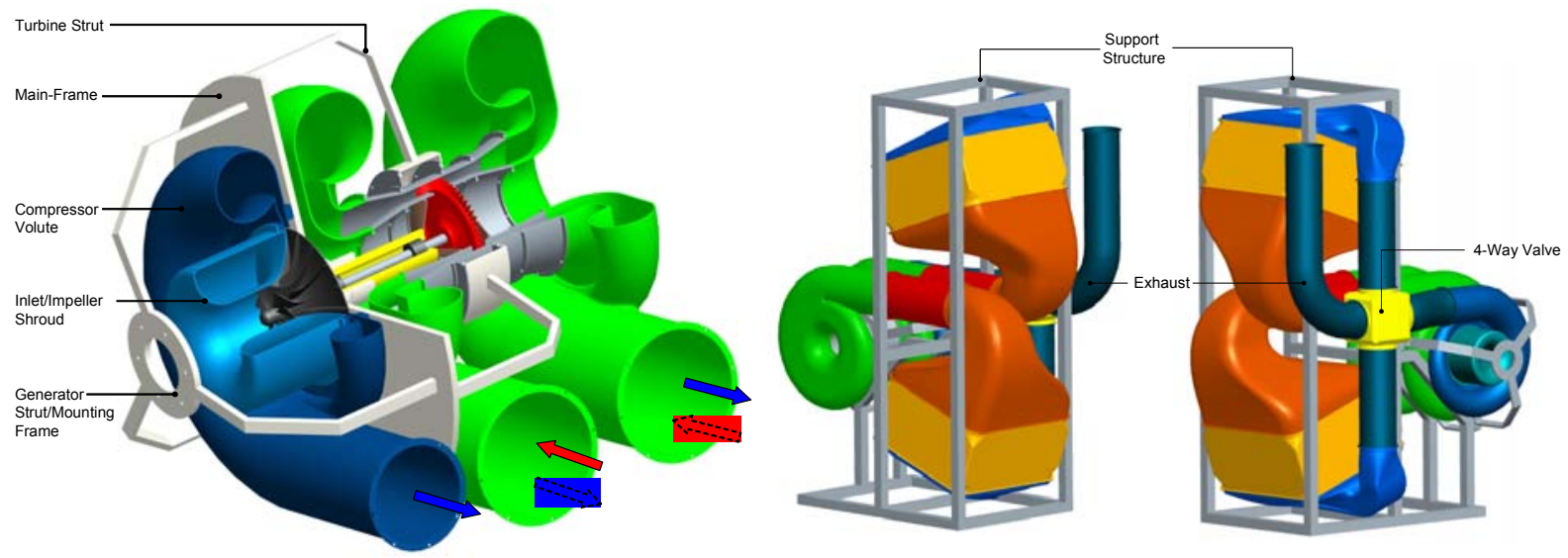

Page 6 of 11 
2. Performance modeling: Following completion of the system design and layout, individual engine components were modeled and incorporated into a system level model to predict overall performance of the proposed system. Summary results and operating parameters are reproduced below:

PFGT Baseline Thermodynamic cycle - "T-s diagram"

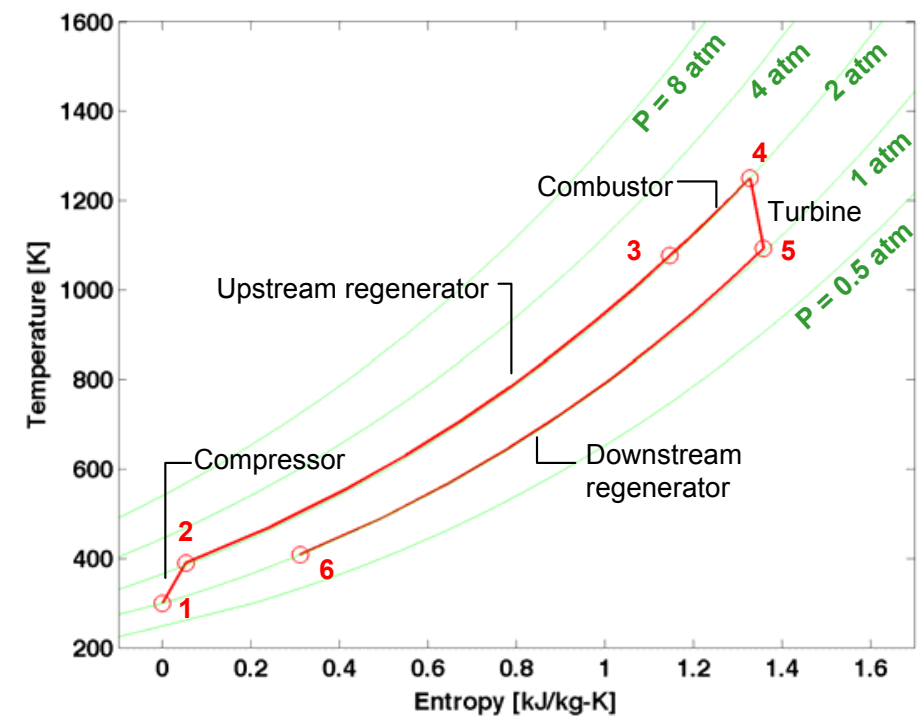

\begin{tabular}{|c|c|c|}
\hline Output & Value & Unit \\
\hline Overall Efficiency & 40 & $\%$ \\
\hline Cycle Efficiency & 46 & $\%$ \\
\hline Power & 100 & $\mathrm{~kW}$ \\
\hline Air Flow & 1.06 & $\mathrm{~kg} / \mathrm{sec}$ \\
\hline Station & $T, K$ & P, atm \\
\hline 1 & 300 & 1.00 \\
\hline 2 & 390 & 2.08 \\
\hline 3 & 1076 & 2.04 \\
\hline 4 & 1250 & 2.00 \\
\hline 5 & 1093 & 1.04 \\
\hline 6 & 409 & 1.00 \\
\hline Input & Value & Unit \\
\hline Pressure ratio & 2.0 & - \\
\hline Max Temp & 1250 & $\mathrm{~K}$ \\
\hline Comp Efficiency & 80 & $\%$ \\
\hline Turb Efficiency & 85 & $\%$ \\
\hline Regen Effectiveness & 97.5 & $\%$ \\
\hline Regen Pres Loss & 6 & $\%$ \\
\hline Burner Pres Loss & 2 & $\%$ \\
\hline Mechanical Efficiency & 95 & $\%$ \\
\hline Generator Efficiency & 90 & $\%$ \\
\hline
\end{tabular}

3. Cost modeling: Concurrent with performance modeling, the stated effort also focused on developing a detailed "bottom-up" cost build-up of the engine to validate initial claims, and provide a range of estimates for the overall system cost (see summary results below).

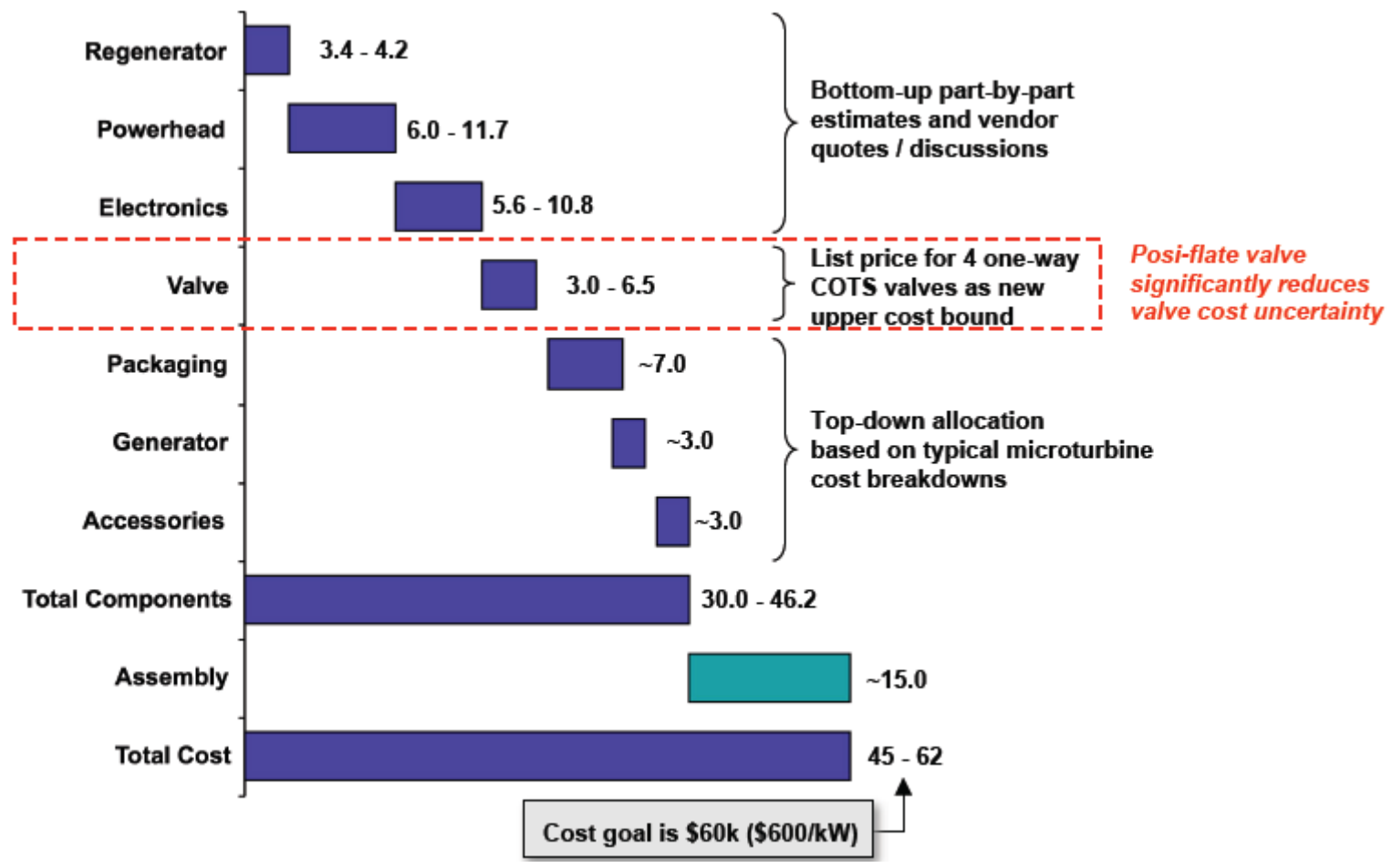


4. Materials selection: Additionally, as part of completing the overall system level design layout, and in support of the aforementioned cost model, a preliminary materials list was also developed for each of the major components under 2 different configuration layouts - this is summarized below as follows:

\begin{tabular}{|c|c|c|c|c|c|}
\hline \multirow[b]{2}{*}{ Component } & \multirow{2}{*}{$\begin{array}{l}\text { Baseline } \\
\text { Material }\end{array}$} & \multicolumn{2}{|c|}{ DUCTED } & \multicolumn{2}{|c|}{ AXISYMMETRIC } \\
\hline & & Qty & Tot Mass, kg & Qty & Tot Mass, kg \\
\hline $\begin{array}{l}\text { Inlet Bell Mouth } \\
\text { Impeller Rotor } \\
\text { Impeller Housing } \\
\text { Shaft } \\
\text { Turbine Disk+Rotor+Blades } \\
\text { Rotor Shroud Housing } \\
\text { Vane Housing / Shroud } \\
\text { Inlet Guide Vanes } \\
\text { Exit Guide Vanes } \\
\text { Radial / Thrust Bearings } \\
\text { Bearing Lubrication System } \\
\text { Vane Actuation "Links" }\end{array}$ & $\begin{array}{l}\text { Plastic } \\
\text { Titanium } \\
\text { Aluminum } \\
\text { Steel } \\
\text { Nickel Alloy } \\
\text { Steel } \\
\text { Steel } \\
\text { Nickel Alloy } \\
\text { Nickel Alloy } \\
\text { Hybrid steel / ceramic } \\
- \\
\text { TBD }\end{array}$ & $\begin{array}{c}1 \\
1 \\
1 \\
1 \\
1 \\
1 \\
2 \\
\text { TBD } \\
\text { TBD } \\
2 \text { sets } \\
1 \\
\text { TBD }\end{array}$ & $\begin{array}{l}0.2 \\
2.8 \\
0.2 \\
1.3 \\
5.0 \\
1.0 \\
6.1\end{array}$ & $\begin{array}{c}1 \\
1 \\
1 \\
1 \\
1 \\
1 \\
2 \\
\text { TBD } \\
\text { TBD } \\
2 \text { sets } \\
1 \\
\text { TBD }\end{array}$ & $\begin{array}{l}0.2 \\
2.8 \\
0.2 \\
2.5 \\
5.0 \\
1.0 \\
6.1\end{array}$ \\
\hline $\begin{array}{l}\text { Regenerator Cold-side Manifold / Header } \\
\text { Regenerator Matrix } \\
\text { Regenerator Housing } \\
\text { Regenerator Hot-side Manifold / Header }\end{array}$ & $\begin{array}{l}\text { Steel } \\
\text { Ceramic } \\
\text { Steel } \\
\text { Steel }\end{array}$ & $\begin{array}{l}2 \\
2 \\
2 \\
2\end{array}$ & $\begin{array}{c}31.5 \\
* \\
20.0 \\
31.5 \\
82.9\end{array}$ & $\begin{array}{l}2 \\
2 \\
2 \\
2\end{array}$ & $\begin{array}{c}20.2 \\
* \\
32.7 \\
45.3 \\
98.2\end{array}$ \\
\hline $\begin{array}{l}\text { External Casing } \\
\text { Internal Liner } \\
\text { Exhaust Contraction } \\
\text { Flame Holders } \\
\text { Fuel Nozzles } \\
\text { Igniters } \\
\text { Fuel Gas Compressor } \\
\text { Fuel Controller } \\
\text { Exhaust Catalyst }\end{array}$ & $\begin{array}{l}\text { Steel } \\
\text { Steel or Ni Alloy } \\
\text { Steel or Ni Alloy } \\
\text { Steel or Ni Alloy } \\
\text { Steel } \\
\text { Steel } \\
- \\
- \\
\text { TBD (if necessary) }\end{array}$ & $\begin{array}{l}2 \\
2 \\
2 \\
2 \\
2 \\
2 \\
2 \\
1 \\
1\end{array}$ & $\begin{array}{c} \\
16.1\end{array}$ & $\begin{array}{c}2 \\
2 \\
2 \\
15-40 \\
15-40 \\
2 \\
1 \\
1\end{array}$ & $\begin{array}{c}20.3 \\
18.3 \\
4.1\end{array}$ \\
\hline $\begin{array}{l}\text { Impeller Collection Scroll (duct only) } \\
\text { Impeller Vaneless Diffuser (axisym only) } \\
\text { Compressor outlet to Valve Inlet } \\
\text { Switching Valve } \\
\text { Valve to Regenerator Cold-side } \\
\text { Regenerator to Combustor } \\
\text { Combustor to Turbine Inlet } \\
\text { Turbine Collection Scroll (duct only) } \\
\text { Valve to Exhaust Nozzle } \\
\text { Generator }\end{array}$ & $\begin{array}{l}\text { Aluminum } \\
\text { Aluminum } \\
\text { Aluminum } \\
- \\
\text { Aluminum } \\
\text { Steel } \\
\text { Steel or Ni Alloy } \\
\text { Steel or Ni Alloy } \\
\text { Aluminum } \\
\text { TBD }\end{array}$ & $\begin{array}{c}1 \\
\mathrm{~N} / \mathrm{A} \\
1 \\
1 \\
2 \\
2 \\
2 \\
2 \\
1 \\
1\end{array}$ & $\begin{array}{c}2.7 \\
1.1 \\
\\
2.8 \\
10.2 \\
6.1 \\
15.2 \\
1.1 \\
39.0 \\
\end{array}$ & $\begin{array}{c}\text { N/A } \\
1 \\
1 \\
1 \\
2 \\
2 \\
2 \\
\text { N/A } \\
1 \\
1\end{array}$ & $\begin{array}{c}1.1 \\
7.4 \\
\\
29.6 \\
38.7 \\
2.0 \\
3.5 \\
82.3 \\
\end{array}$ \\
\hline TOTAL (Primary metal parts only): & & & 155 & & 241 \\
\hline
\end{tabular}

Note: The initial design of the periodic flow combustor initially also considered an axi-symmetric configuration; this was subsequently abandoned in favor of the previously described "ducted" layout due to weight and simplicity considerations.

5. Vane actuation rig design, development and testing: Following completion of the overall system design and layout, the stated effort transitioned into component validation, beginning with design of a vane test rig intended to validate the ability to passively actuate a set of turbine nozzle guide vanes for reversible, bi-directional flow (a schematic concept for the same is shown in the adjacent diagram).

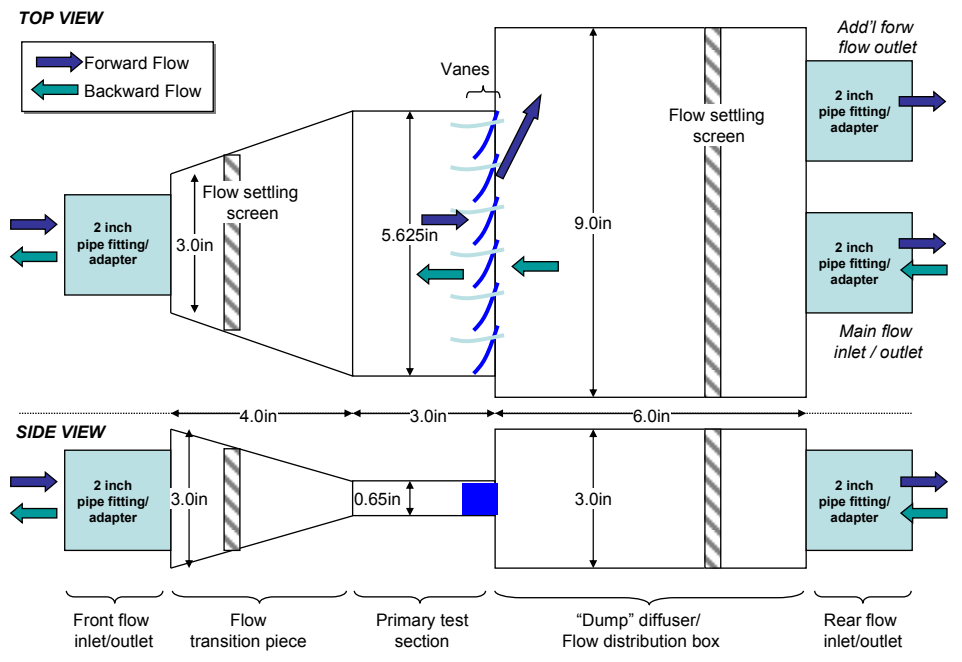


The design of the specific vane segments was also completed on a progressive basis using CFD tools to evaluate the flow angle and pressure losses under forward and reversible flows; a sample result is shown alongside for 2 such designs.

The final design was converted into hardware using a variety of vendors to manufacture each of the components, and then assembled in-house into a test stand (see pictures below). Testing of the same was also conducted in-house, and showed satisfactory actuation of the vanes under aerodynamic forces upon switching flow direction (videos of this test have previously been submitted to the PM, and are available on request).
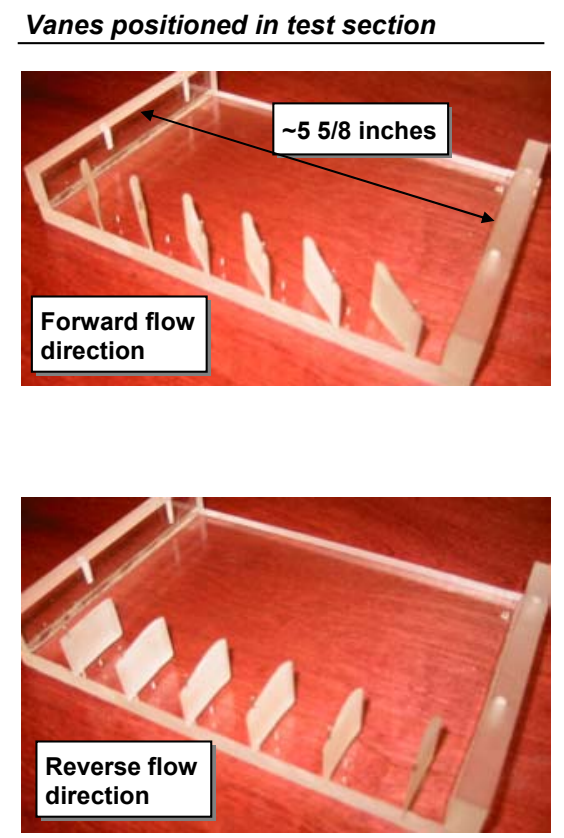

Full test section assembled in cart

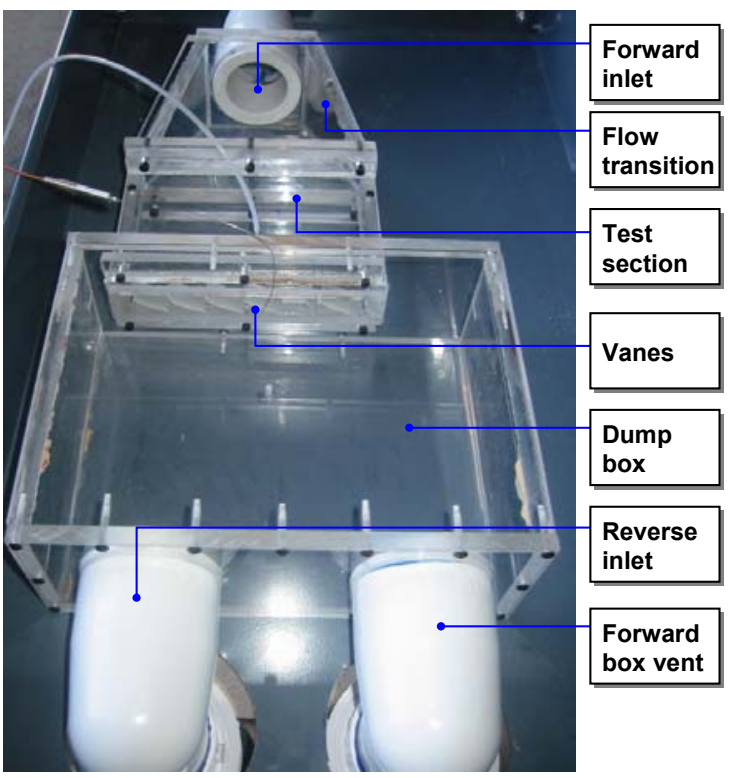

6. Combustor pressure loss evaluation: Since operation of the periodic flow turbine requires a combustor with low pressure loss in forward and reverse flow, the stated effort also examined multiple configurations for a suitable combustor design, and used CFD tools to evaluate the pressure loss under bi-directional flow conditions.

Sample results from one such simplified configuration are presented alongside as evaluated using 2 different codes, and show satisfactory levels of pressure loss under both conditions.

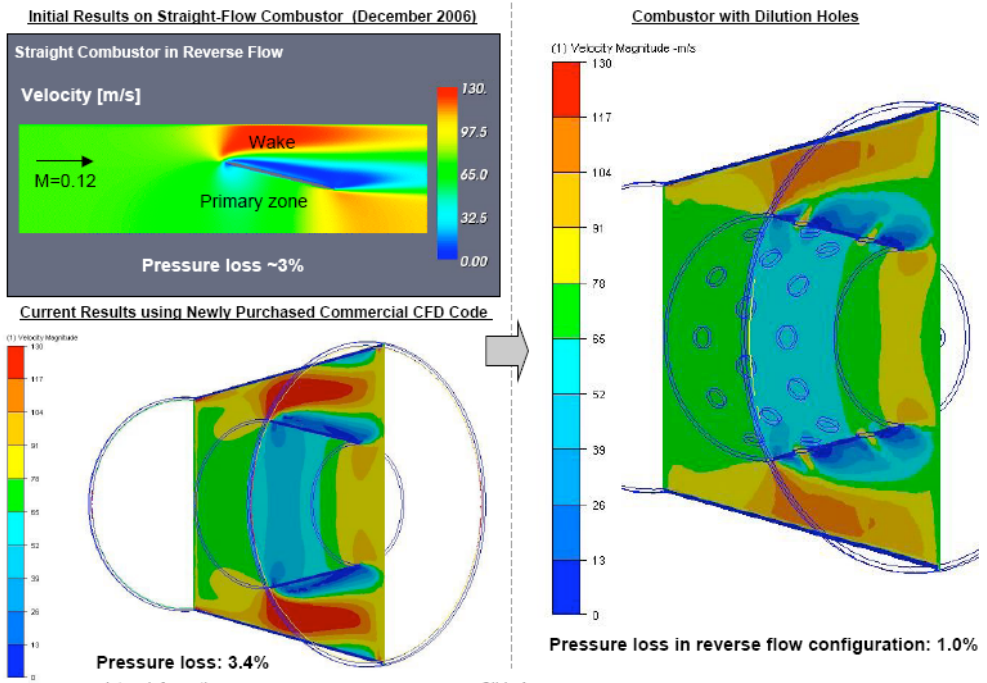


7. Valve research, procurement and testing: Identification of low-cost, long-life and fast actuating valves for periodic switching of the flow is also a critical high-risk item for eventual success of the proposed concept, hence, significant effort was spent in laying out the design requirements and evaluating the pros and cons of various commercial-off-the-shelf solutions (see table below identifying design requirements and corresponding limitations of most existing valve types).

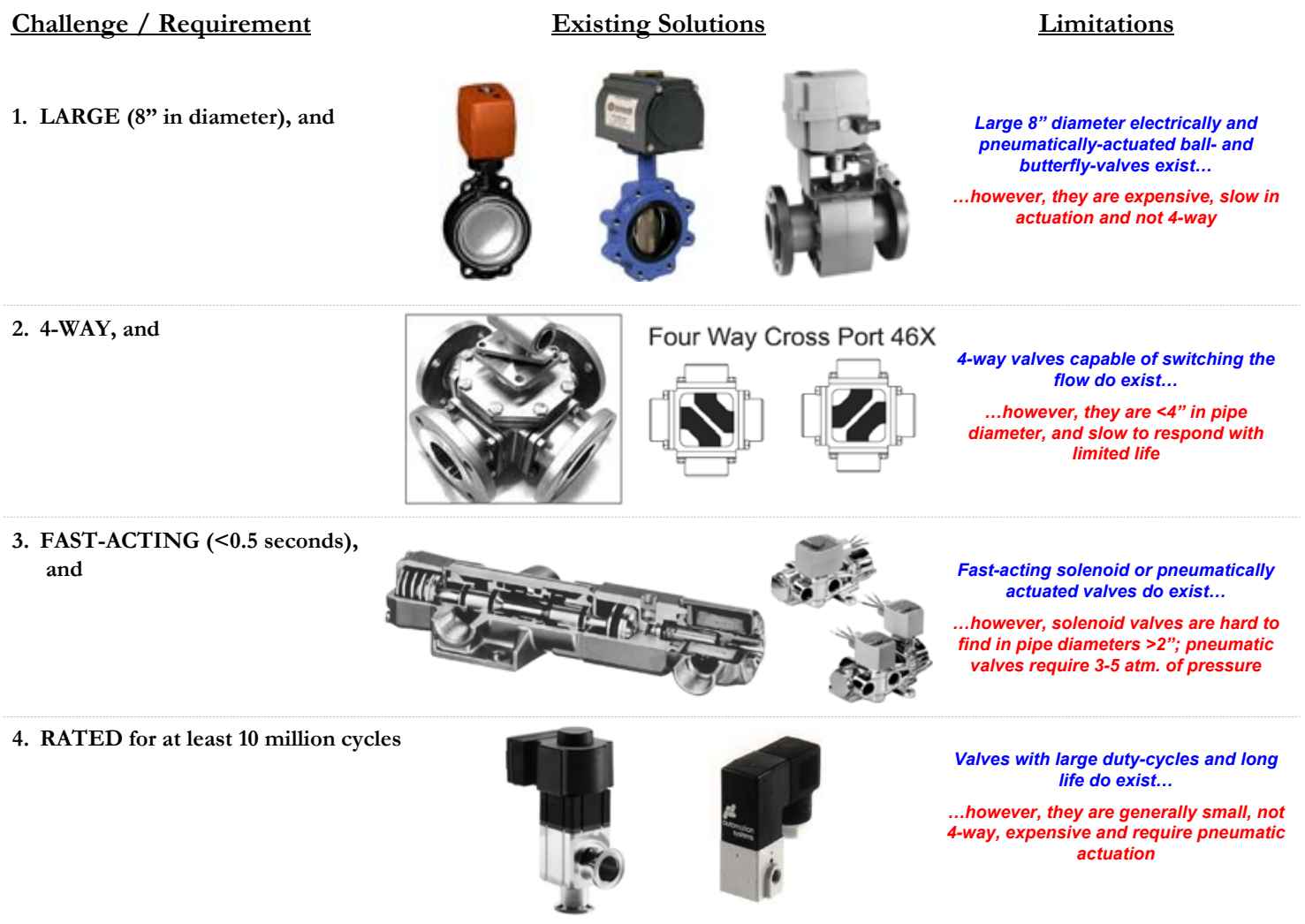

Upon further research, an innovative set of butterfly valves were identified as a suitable option (information on these is not being included in this report).

As part of the stated effort, a set of 4 such valves were also procured and assembled in a 4-way switching valve configuration; the actuation times and control sequence was determined to be satisfactory for eventual integration in a periodic flow gas turbine system.

8. Combustor test rig design, assembly and testing: The 4-way valve set-up was further integrated into a combustor test rig intended to evaluate the performance of a "regenerator-like" ceramic pre-heater in improving combustion stability and flammability limits (see test rig picture below).

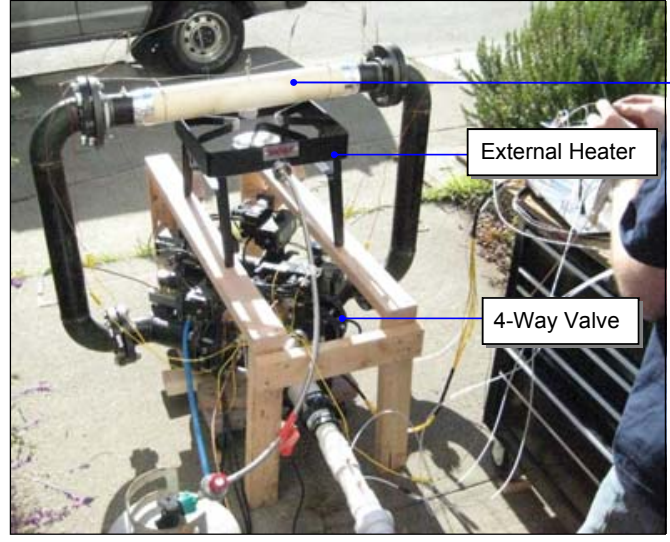

Page 10 of 11

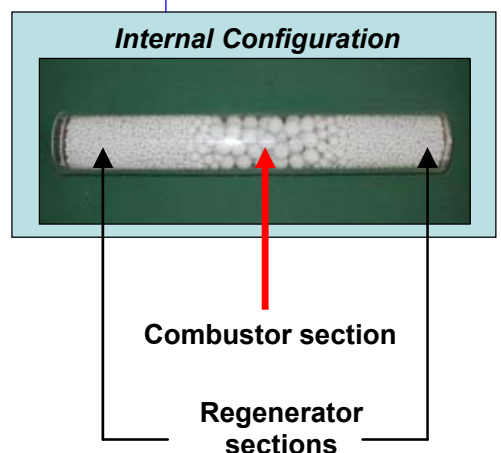

sections 
The combustion test rig was successfully tested and showed that lean pre-mixed combustion within the pebble bed with an equivalence ratio of 0.4 increased the combustor temperature to approximately $1,100 \mathrm{~K}$ (see data on following page); additional work in this area is still required to better characterize the performance of a reversed flow combustor and regenerator system.

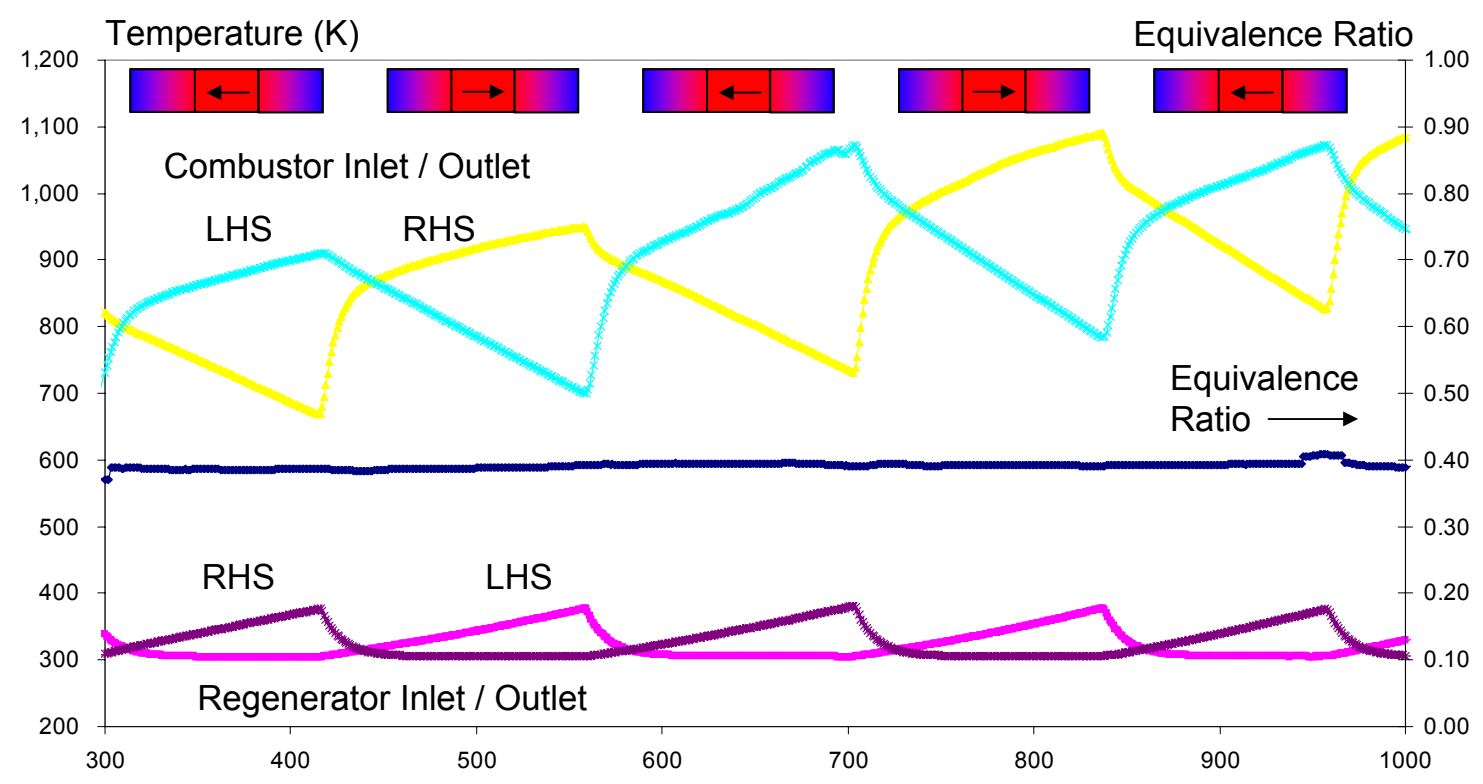

Products Developed AND TeChNOlogy Transfer ACTIVITIES

The project resulted in fabrication of several experimental rigs that provided important information towards eventual development and commercialization of a periodic flow gas turbine product. Simultaneously, Ventions submitted a full patent for the proposed concept on November $20^{\text {th }}, 2006$ (a provisional patent for the same had already been filed in 2005 prior to start of the project). 